\title{
Distribution, status and taxonomy of the near-threatened Black-bodied Woodpecker Dryocopus schulzi
}

\author{
A. MADROÑO NIETO and M. PEARMAN
}

\begin{abstract}
Summary
Studies of records of the Black-bodied Woodpecker Dryocopus schulzi through literature searches, communications with ornithologists, personal observations and data from museum specimens show that the distribution of the species is basically limited to xerophytic chaco woodlands in western Paraguay, northern and central Argentina, and southern Bolivia. Its western limit is defined by the transition zone between the chaco and the semi-humid montane forest on the east Andean slopes of southern Bolivia and north-west Argentina; in the extreme south it extends into the dry deciduous woodlands in the sierras of Córdoba and north-eastern San Luis. The taxonomic history of the species has been chequered; we present morphological and vocal differences from its closest relative that reaffirm its specific validity. It appears to have suffered an alarming decline over much of its former range in Argentina, and appears to survive only in two isolated population centres of significant importance, in Córdoba and adjacent San Luis and in the central part of the Paraguayan chaco. The main cause of its rarity is destruction of habitat for timber extraction and expansion of agriculture and cattle-raising.
\end{abstract}

El estudio de registros del Carpintero Negro Dryocopus schulzi mediante revisión bibliográfica, comunicaciones de ornitólogos, observaciones personales e información adjunta a especímenes en museos, muestra que la distribución de la especie básicamente se circunscribe al bosque chaqueño de carácter xerófilo del oeste de Paraguay, norte y centro de Argentina y sur de Bolivia. Su extremo occidental alcanza la zona de transición entre el chaco y los bosques semihúmedos montanos en las sierras orientales andinas del sur de Bolivia y del noroeste argentino; en el extremo sur se extiende hasta los bosques secos decíduos de las sierras cordobesas y del noreste de San Luis. La historia taxonómica de la especie ha sido confusa; las diferencias morfológicas y vocales que aquí se presentan y comparan con su pariente más próximo reafirman su validez específica. Parece haber sufrido una disminución preocupante en la mayor parte de su distribución original en Argentina, y quedan aparentemente tan solo un par de núcleos poblacionales aislados de cierta importancia, en Córdoba y zona adyacente de San Luis y en la zona central del chaco paraguayo. La principal causa responsable de su rarefacción se debe a la destrucción del hábitat por la explotación de los recursos madereros y a la creciente expansión de la frontera agrícola y ganadera.

\section{Introduction}

The Black-bodied Woodpecker Dryocopus schulzi is restricted to the central and southern chaco, in Bolivia, Paraguay and Argentina, and to the transitional subtropical forest at the low eastern edge of the Andes in southern Bolivia and north-west Argentina (see Figure 1). It was originally a candidate for inclusion 


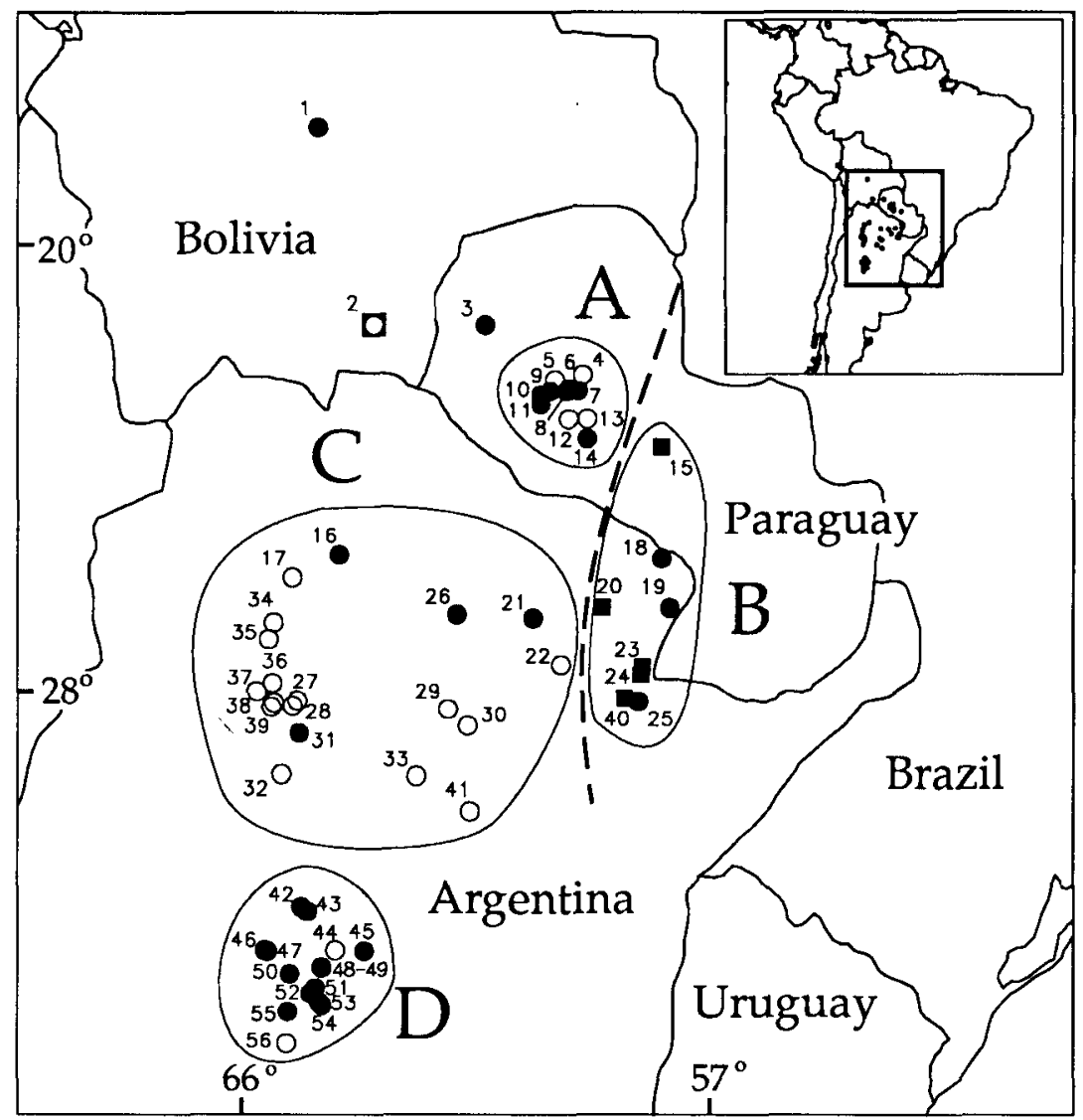

Figure 1. The distribution of Dryocopus schulzi showing historical ( $\bigcirc$ pre-1970), recent (• post-1970) and hybrid ( $\square$ ) records. Ringed areas represent the central dry Paraguayan chaco (A), humid chaco where most hybrids have been reported (B), dry chaco and transitional forest (C), and Córdoba and San Luis transitional (D); dashed line roughly separates dry chaco (to the west) and humid chaco to the east (following Hueck's 1972 map). See Appendix for key to numbered localities.

in Threatened birds of the Americas (Collar et al. 1992), as its distribution and habits were poorly known (e.g. Short 1975, 1982) and most published information and correspondence (with ICBP) remarked on its scarceness (see Population below). However, after deeper investigation in the literature and further inquiries to other ornithologists with field expertise in the region, it was decided to confine it to "near-threatened" status, adopted by ICBP as a term for "birds which, while apparently not (yet) seriously in danger of global extinction, give cause for concern" (see Collar et al. 1992). However, it was also agreed that in due course the analysis already begun on the species should be completed and published, partly because it is clearly valuable to review the status of such borderline species whenever possible, and partly because this bird is a particularly interesting representative of the chaco fauna: any conservation initiatives in the chaco should certainly take the species into account. 


\section{Methods}

This paper constitutes a compilation of all published and unpublished information (available to us) on the Black-bodied Woodpecker. Museums are referred to in the text by abbreviations as follows: AMNH, American Museum of Natural History; ANSP, Academy of Natural Sciences of Philadelphia; BMNH, British Museum of Natural History (Tring); IML, Instituto Miguel Lillo (San Miguel de Tucumán); MACN, Museo Argentino de Ciencias Naturales, Buenos Aires; MCZ, Museum of Comparative Zoology (Cambridge, U.S.A.); UMMZ, University of Michigan Museum of Zoology. Part of the museum data was gathered by N. J. Collar during the early stages of preparing Threatened birds of the Americas; M. LeCroy provided the information from AMNH, J. R. Navas from MACN, R. A. Paynter from MCZ, R. W. Storer from UMMZ, while we ourselves studied the specimens held in BMNH. Considerable data were collected through personal communications with ornithologists familiar with the species and from our own observations in Argentina and Paraguay.

In the Appendix, records are organized within countries and provinces or departments (from north to south); coordinates are derived for every traced locality, which have been numbered and mapped in Figure 1; the coordinates are generally provided from the original source (published or not) or by reference to ornithological gazetteers (Paynter et al. 1975, Paynter 1985, 1989) or DSGM (1988). Most localities in Figure 1 have been circumscribed in four general areas (A-D) in order to facilitate discussion in different parts of the text. At least one source for each record is provided, although on several occasions several sources have been included in order to facilitate further research; for this same reason if specimens exist, the relevant museum (if known) is also given (very often collecting dates and descriptions of specimens are incomplete or lacking in the literature, but information in museums has greatly compensated for this deficiency). Approximate altitude of the record (provided in the original source or obtained from the gazetteers) is given if available, but no attempt has been made to provide figures for localities throughout the vast low chaco plain, where elevations move gradually from below $100 \mathrm{~m}$ near the Paraguay river in the east to $450 \mathrm{~m}$ in areas at the base of the Andes in the west (Short 1975, Paynter 1985, 1989).

Six study tapes of calls of Lineated Woodpecker $D$. lineatus from wide-ranging South American localities were compared with two available study tapes of $D$. schulzi from two different localities in Córdoba, Argentina (tape-recorded and published by R. Straneck; a copy is held in the British Library of Wildlife Sounds, National Sound Archive, London).

\section{Taxonomy}

The taxonomy of the Black-bodied Woodpecker has been the subject of much uncertainty, with various changes at both subspecific and specific level. The existence of several hybrids between lineatus and schulzi (see Appendix and below) and descriptions of invalid taxa (see below) have helped to muddle the already puzzling taxonomic position of the species.

Cabanis (1883) first described the species under the genus Phloeotomus, 
although later generic designations of the species, or hybrids with lineatus, included: Campephilus, Ceophloeus, Dryotomus, Neophloeotomus (e.g. Dabbene 1915, Cory 1919, Peters 1948, Pergolani de Costa 1962), all of which were eventually synonymized (including the lineatus and pileatus allospecies) in Dryocopus (Peters 1948; also Pergolani 1941). However, this genus (Dryocopus) was fortuitously applied to the species by Burmeister (1861) (before it was known to science) when he referred to an immature "D. [Dryocopus] atriventris" (= Creambacked Woodpecker Campephilus leucopogon), which, according to Cabanis (1883), was an individual belonging to the newly described species (schulzi) (see also Sclater and Hudson 1888-1889).

Dabbene (1915) described a new species ("shiptoni") from Tucumán, which was identical to schulzi but for a white scapular bar; however, this taxon (although accepted by Cory 1919) was discarded by Dinelli (1931), who referred to the existence of specimens of schulzi (including paired birds) with and without this plumage feature. His opinion was supported by Mogensen (1932), who attributed this characteristic to the close relation with $D$. lineatus. The evidence of these two latter authors was not, however, followed by SOMA (1938) or Olrog (1959), who maintained specific distinction between schulzi and shiptoni, although the latter was soon after (and finally) discarded (Pergolani de Costa 1962, Short 1975, Olrog 1979).

A further taxonomic problem was introduced in 1916 by $R$. Dabbene, who described yet another race of schulzi, namely "major" (see Dabbene 1916, 1926). Both Mogensen (1932) and Pergolani de Costa (1962) believed this to be a good species, the former suggesting the name "Ceophloeus ater" and the latter "Dryocopus major"; nevertheless, the distinction was not accepted by Short (1975, 1982), who considered the form in question to represent a hybridization between schulzi and lineatus. Furthermore, Peters (1926) described the subspecies "Dryocopus erythrops fulcitus" (type-specimen in MCZ; see also Peters 1948), which was also later considered a hybrid between lineatus and schulzi (Short 1982).

A similar taxonomic problem to that of "shiptoni" (possessing white scapular bars) led to the description of "D. erythrops" (see Peters 1948), which represents lineatus without the white scapular bar, but again the specific distinction was not accepted, the form being relegated to subspecific level (i.e. D. l. erythrops) (Pergolani de Costa 1962, Short 1975, 1982, Sibley and Monroe 1990). Interestingly, in the south-east of the Lineated Woodpecker's range the race erythrops is distinctive (i.e. all birds lack the white bar), with a zone of overlap where both nominate lineatus and erythrops "morphs" are present (see figure 37 in Short 1975), whereas within the range of schulzi no such isolation is present inasmuch as both morphs (typical schulzi and the white-scapulared "shiptoni") can be found mixed throughout (see above) and, although southern birds are smaller than those from the northern chaco, variation is clinal (Short 1975, 1976, 1982).

Despite the morphological and ecological differences between lineatus and schulzi indicated by Short (1982), that author (p.412) remarked that "whether or not it [schulzi] is specifically distinct from lineatus is a moot point". However, comparisons between the common call type of lineatus and schulzi through sonagraphic analysis tend to confirm that both represent valid taxa (see below); 
furthermore, the following obvious morphological differences are judged sufficiently important as definitely to maintain schulzi's full specific status: (a) the red crown in schulzi females extends over most of the forehead leaving only $c .0 .5 \mathrm{~cm}$ (or less) of grey feathering above the base of the bill, whereas $c .1 .5 \mathrm{~cm}$ (or more) of grey is exposed in lineatus; (b) schulzi has pale grey or whitish ear-coverts, whereas in lineatus this area is black or dark grey; (c) the throat in schulzi is white to dirty grey with or (usually) without fine brownish streaks (also Short 1982), whereas in lineatus it tends to be heavily streaked giving a much darker appearance; (d) bill colour in schulzi is predominantly white, whereas in lineatus it is typically blackish to grey; (e) nine specimens in BMNH were labelled as having "coffee" and "bright coffee" irides, whereas in lineatus eye colour varies from white to pale yellowish orange, although the young may have brown eyes at first (Short 1982; also his plate 77); (f) belly, flanks, vent and undertail-coverts are black in schulzi, sometimes with very fine barring, usually on the flanks and abdomen, unlike lineatus which always shows heavy barring; (g) underwing-coverts are white in both species, but schulzi presents an irregular, usually large black patch (sometimes nearly lacking: Short 1982) on the bend of the wing, whereas in lineatus this same area is entirely white, although occasionally with a small or, rarely, moderately sized black patch (Short 1982); (h) the rectrices in schulzi show white shafts (visible in the field and on BMNH specimens) which are dark in lineatus.

The vocalizations on both sets of (schulzi and lineatus) recordings appear to be constant in form and duration between different localities: the loud ringing "wick wick wick" call types of schulzi and lineatus (see Figure 2) are very similar in the quality, structure and frequency of their notes, with the fundamentals and double harmonies of lineatus falling within the frequency ranges of those of schulzi. The vocalizations do, however, differ as follows: (a) the schulzi vocal-

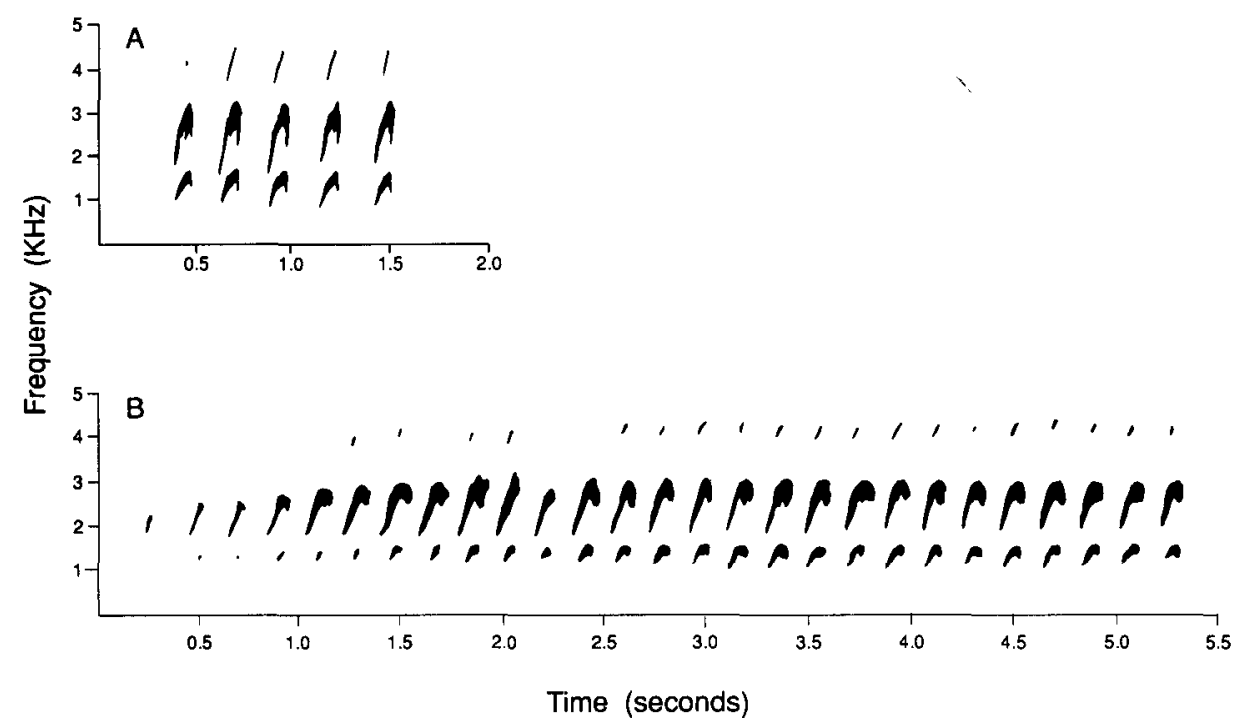

Figure 2. Sonagrams of typical calls of Dryocopus schulzi (A) and D. lineatus (B) in the $300 \mathrm{~Hz}$ bandwidth. 
ization is delivered at four notes per second compared with the faster delivery of lineatus at six notes per second; (b) schulzi shows a broader pitch variation (see Figure 2); (c) schulzi typically delivers only five notes compared with 29 (mean from six study tapes) in lineatus. It should be noted that schulzi is capable of delivering a longer variation of this call type, although it has only been reported by one observer, and was then judged to be atypical; we would expect differences between (a) and (b) mentioned above to be constant within such a vocalization. The differences between calls in this analysis suggest that schulzi is specifically distinct from lineatus, but only a small sample for schulzi was available and the evidence presented here therefore needs further investigation.

A second vocalization, "ti-chrr", with the second note being a harsh rattle, is very common in lineatus but rare in schulzi; we have been unable to make a sonagraphic comparison in the absence of a recording of this call type for schulzi. It should be noted that drumming of the two species is very similar, with lineatus giving 17.8 strokes per second (mean from five study tapes), and schulzi giving 17.6 strokes per second (mean from two study tapes), whilst duration of the drum (the same study tapes) was 1.2 seconds in schulzi compared to 1.6 seconds in lineatus, although a factor such as the state of prenuptial activity presumably precludes the possibility of a valid comparison.

Whilst the morphological and vocalization differences (regardless of the ecological habitat preferences: see Short 1975, 1982; also Ecology below) are judged important enough to maintain schulzi as a valid species, the high number of hybrids recorded in areas of sympatry (area B in Figure 1), general structure of call types (see above and Figure 2) and certain phenotypic characters occasionally present in both species (i.e. a character not expected for schulzi but for lineatus and vice versa) serve to emphasize the common ancestral origins of these two species.

\section{Distribution}

The Black-bodied Woodpecker has a relatively restricted range in south-central South America, where it has been recorded from south-central Bolivia (Santa Cruz and Tarija; see Remarks 1), western Paraguay (Nueva Asunción, Boquerón and Presidente Hayes) and north-central Argentina (Salta, Formosa, Chaco, Tucumán, Santiago del Estero, Corrientes, Santa Fe, Córdoba and San Luis) (see below; also Figure 1).

\section{Bolivia}

The species is only known from two localities in the central and southern parts of the country on the eastern slopes of the low Andes (see Figure 1 and Appendix). The recent record from Comarapa, Santa Cruz (record no. 1), extends the previous known range to the north by $c .375 \mathrm{~km}$, and it seems likely that birds will also be found in appropriate habitat in between (see Ecology). Furthermore, the record of a bird at Teniente Enciso, in the Paraguayan chaco near the Bolivian border (record no. 3), suggests that the species probably occurs in the chaco lowlands of eastern Chuquisaca and Tarija near the Paraguayan border. 


\section{Paraguay}

All records are west of the Paraguay river where all but one (from Nueva Asunción) are from Boquerón and Presidente Hayes departments. The record at Teniente Enciso in extreme western Paraguay suggests that the species occurs throughout the dry chaco westward to the eastern environs of the low Andes in Bolivia. The species appears to be absent from the northern chaco (Chaco department) and from south-eastern Santa Cruz department (Bolivia), where it has never been recorded (e.g. Short 1975, Remsen and Traylor 1989, Hayes et al. 1991; also in fieldwork by A.M.N.). The northern limit of the species's range in the Paraguayan chaco is yet to be ascertained.

\section{Argentina}

Most of the records in the country are from the western edge of the chaco in the foothills of the eastern sierras of the Andes in the provinces of Salta, Tucumán, Santiago del Estero and from the sierras of western Córdoba; however, the species also occurs to the east in the chaco lowlands reaching eastern Formosa, Chaco and Corrientes (for hybrids with lineatus see Figure 1 and Appendix) and north-west Santa Fe (Corrientes and Santa Fe provinces are not mentioned, or included, in the distribution maps given by Narosky and Yzurieta 1987 and Canevari et al. 1991). Dabbene (1926) referred to a female collected at Santa Ana, Misiones, by F. M. Rodríguez (this specimen, according to him, had been sent to MACN), and to a second specimen taken in the "same territory" by E. Budin. We have been unable to trace the location of either of the above-mentioned specimens, which are presumably the source of other authors listing the species for that province (e.g. SOMA 1938, Peters 1948, Pereyra 1950, Olrog 1959, 1963). It is likely that there was a confusion with $D$. lineatus (for which there is a large series from the same locality: see, e.g., Pergolani de Costa 1962). Later reviewers and maps of the species's distribution (see, e.g., Olrog 1979, Narosky and Yzurieta 1987, Canevari et al. 1991) excluded the province from its range, and there appears to have been no further mention of these two specimens from Misiones. The southernmost known locality for the species is in north-eastern San Luis province at $32^{\circ} 50^{\prime} \mathrm{S}$ (see Appendix and Figure 1).

\section{Population}

\section{Bolivia}

The species appears to be very rare; there are only four records from two localities (in 1936 and 1991, one a hybrid: see Appendix). The record from Valle de Comarapa, Santa Cruz, much the northernmost site for the species, suggests that it may occur in the intervening region (see Figure 1), although T. A. Parker (verbally 1992) has not found it in the above-mentioned area despite extensive fieldwork there, nor did J. Fjeldså and S. Maijer during long treks in the premontane zone of Chuquisaca in September-October 1991 and March 1992 (J. Fjeldså in litt. 1992). However, as already stressed in Distribution, it is likely that the species occurs in the chaco woods of Chuquisaca near the border with 
Paraguay, where there is still extensive undisturbed forest (A.M.N. pers. obs.). The paucity of records from the country does not allow an assessment of past status, and it remains unclear as to whether the species has suffered a considerable decline or was always very rare there.

\section{Paraguay}

Very little is known about the status of the species over a large part of the country. Most records come from the central chaco between Boquerón and Presidente Hayes departments (area A in Figure 1) within the environs of Mennonite colonies (i.e. Filadelfia, vicinity of Lichtenau, Loma Plata, Colonia Neuland, Orloff; see Appendix). These records suggest that the species was once and perhaps still is at least locally common (at least 13 specimens were collected in the early 1970s; also Short 1976). Neris and Colmán (1991) found the species "abundant" (i.e. "found daily" in their study area; see Appendix) between April 1988 and March 1989, suggesting that it has not suffered a notable decline; however, Neris and Colmán's (1991) categorization should be treated with caution because daily observations in one particular locality or area may well represent repetition of sightings of the same individual(s). Furthermore, A.M.N. spent a total of two months during the winter of 1989 and 1990 at site no. 10 (see Figure 1), which is very close to the locality indicated by Neris and Colmán (1991), but only observed a single individual, whereas other species of Picidae were frequently encountered. It is also worth mentioning that F. E. Hayes (in litt. 1991, 1992) spent roughly a month in the central Paraguayan chaco, where he observed two different birds on the same day twice at localities nos. 7,8 and 9 (see Appendix). The lack of additional records from the remaining Paraguayan dry chaco (at least near the Bolivian border) presumably reflects the lack of fieldwork in this area and the species's status there remains, for the time being, undetermined.

\section{Argentina}

After the species was described (Cabanis 1883; see Remarks 2) Stempelmann and Schulz (1887) listed it for the province of Córdoba as a permanent resident ("not rare": Frenzel 1891), and Lillo (1902) also included it in his list of the birds of Tucumán; however neither of them gave an indication of its status. By 1910 the species had still only been recorded from the above-mentioned provinces (Dabbene 1910). Ménégaux (1925) reported it for Santiago del Estero for the first time (vicinity of Icaño), thus considerably extending the previous known range south-south-east into the chaco lowlands. He described nesting habits (see Ecology) and referred to pairs and groups of "five to six individuals"; furthermore he indicated that the species was very rare in collections, as already noted by Dabbene (1915). Dinelli (1931) collected 11 birds at Las Termas, Santiago del Estero, between 10 and 21 September 1930; although he did not refer to the status or abundance of the species, the large number of specimens taken suggests that it was at least locally common in the area. Mogensen (1932) referred to the scarcity of the species in Tucumán, despite there being at least 22 specimens collected in the province between 1909 and 1928 (18 of which were taken 
between 1909 and 1918; see Appendix). Nores et al. (1983) judged it to be "fairly scarce" in Córdoba, an opinion shared by D. Willis (in litt. 1991); Narosky and Yzurieta (1987) considered it "rare or very difficult to find"; Canevari et al. (1991) judged it "rare" throughout its range and "poorly known", and M. Nores (in litt. 1992) believes it to be scarce although remarking that it appears always to have been so. The evidence presented above suggests that the population in the Argentine chaco (area $C$ in Figure 1) may have declined severely, there being only four recent (post-1970) records (see Figure 1 and Appendix) compared with 30 (from 15 different sites; see Remarks 3 and Threats) historical (pre-1970) records. In the sierras of Córdoba (Grande/Comechingones) and nearby areas (e.g. north-east San Luis province, area D in Figure 1), the species has been recorded more often (although considered scarce: see above) and there are recent (post-1970) records for most known localities, in some of which (e.g. nos. 43. 51, and 46) it is regularly observed (Canevari et al. 1991, R. J. Straneck in litt. 1992; also Appendix). In this region the Black-bodied Woodpecker appears to be relatively safe in those areas where the forest remains fairly well preserved. The area B (in Figure 1), i.e. humid chaco, is considered possibly atypical habitat for the species (see below; also Short 1975), with five of the eight records there being hybrids, and the occurrence of the species in it may be only occasional: for instance, in Río Pilcomayo National Park there were only two sightings in c. 8 years in the 1980 os by a park guard (verbally to M.P.), and many ornithologists visited the area without observing the species (J. C. Chebez in litt. 1992; see Remarks 4). Finally, it is worth noting the lack of records between areas $A$ (in Paraguay) and C (mainly in north-east Salta and the western parts of Formosa and Chaco), which may be attributable to a general lack of fieldwork in the area.

\section{Ecology}

The Black-bodied Woodpecker inhabits the central and southern dry chaco of Paraguay, Bolivia and Argentina, the isolated mountain range of Sierra Grande/Comechingones of western Córdoba and north-eastern San Luis, and the fringe of the east Andean sierras in Bolivia and Argentina. In the latter ecotone, the vegetation where the species occurs is a transitional gradation between the chaco and that of the high sierra, being above 1,500 $\mathrm{m}$ (Short 1975, 1982, Nores et al. 1983, Clarke 1991, data in this paper: Remarks 5; Figure 3). The highest elevation at which the species has been recorded is $1,800 \mathrm{~m}$ (in Santa Cruz, Bolivia) (Clarke 1991), but most records are below 1,000 m (see Appendix). At the above-mentioned locality (no. 1), the habitat where the species was observed corresponded to the division between semi-humid montane forest with a predominance of Alnus and Tipuana and semi-arid intermontane vegetation, where more xerophytic vegetation was dominated by cacti spp., Acacia, Prosopis, Schinopsis and Tipuana (Clarke 1991; also Remsen and Traylor 1989). The species is unrecorded north of Joaquín V. González, Salta, in the continuing strip of montane forest (semi-humid forest or "yungas") which extends into Bolivia, where extensive fieldwork has been conducted in Calilegua National Park, Jujuy, and Baritú National Park, Salta, indicating that the species has never occurred in this ecotone. Within the humid chaco (see Figure 1), the 


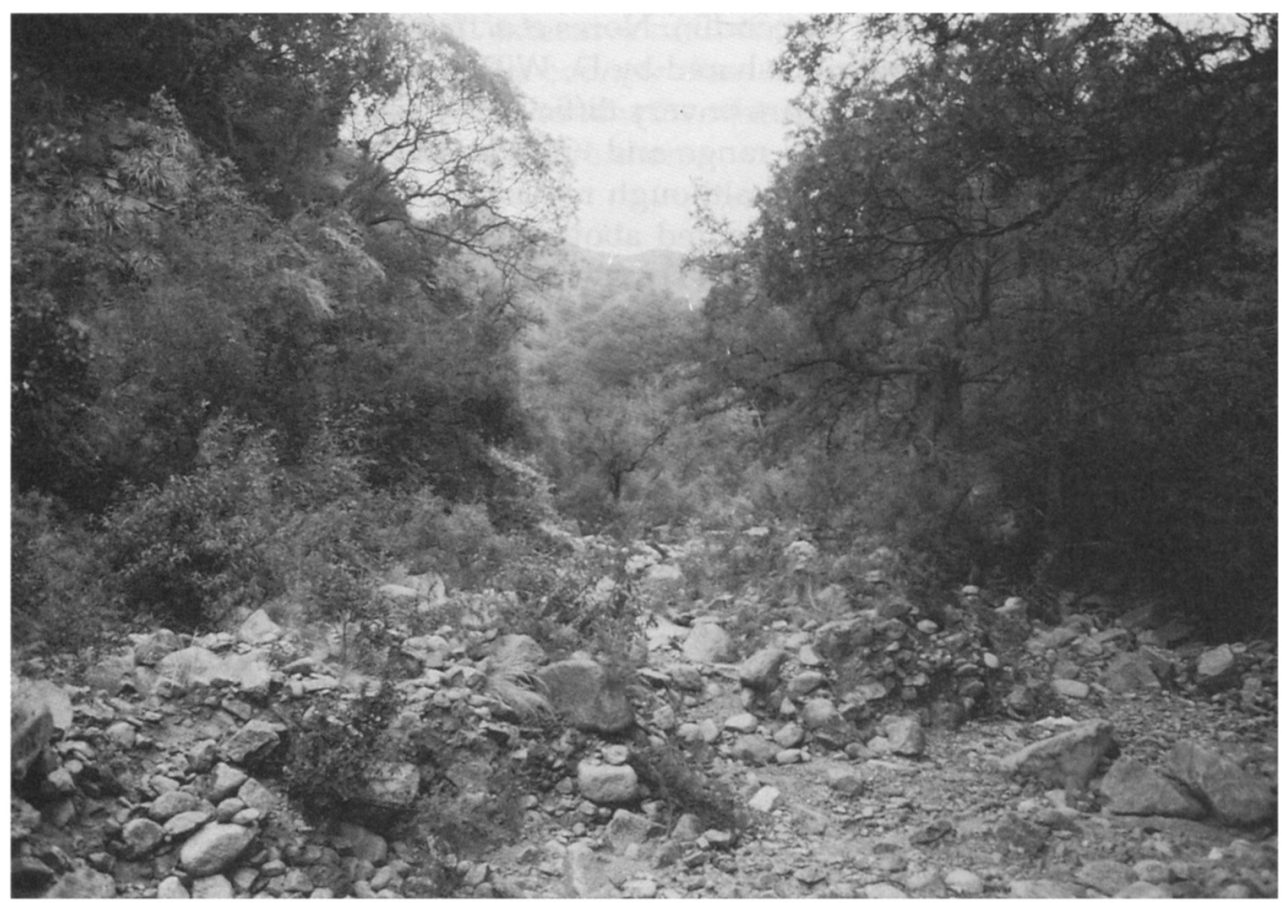

Figure 3. Transitional woodlands at Cerro Uritorco, Sierra Grande, Córdoba, Argentina, March 1991 (photo: M. Pearman).

species has rarely been recorded in Formosa (two records); at Río Pilcomayo National Park birds were observed in an isolated woodland dominated by Prosopis sp. surrounded by marshland (park guard verbally to M.P.). Given that five of the seven other humid chaco records refer to hybrids (see Figure 1 and Appendix), it seems conceivable that the humid chaco is unusual habitat for the species, and further investigation on this hybridization zone needs to be conducted in order to shed more light about the status of the species there.

Brief descriptions of the habitat where the species has been recorded in the dry chaco of central western Paraguay (Boquerón department) can be found in Steinbacher (1962) and Neris and Colmán (1991); R. Straneck (in litt. 1992) describes the area where he has observed the species on different occasions (locality no. 51) as dominated by Lithraea molleoides, Celtis tala and Acacia caven (see also Nores et al.'s 1983 descriptions of the vegetation of this general area). For more detailed descriptions of the vegetation throughout the species's range see, e.g., Hueck (1978), SAB (1982) and Spichiger and Ramella (1989). M. Nores (in litt. 1992) has reported that the species also appears in semi-modified areas, perhaps thus indicating a degree of adaptability to environments affected by man.

There is no information about food or feeding behaviour other than that foraging occurs on trunks and major tree limbs in typical woodpecker fashion (pecking and probing, hammering, etc.) (B. M. Whitney in litt. 1991, pers. obs.). The breeding season has been given as October and November, with a moult following nesting from February to April (Short 1982); two birds collected in 
October in the vicinity of Lichtenau had enlarged gonads (Short 1976). The nest is drilled in the trunk of dead trees (Ménégaux 1925); a pair bred in a telegraph pole by a secondary road at Alta Gracia, Córdoba (M. Nores in litt. 1992); a pair frequented a roost/nest hole in a dead tree in May 1991 (M. Sulley verbally 1992), and a bird was observed drumming on a telephone pole in March 1991 (F. R. Lambert verbally 1992).

Pairs or single birds are usually reported. However, Ménégaux (1925) observed groups of five or six birds (presumably a family group). Nothing is known about seasonal displacements or other questions such as territory size, clutch-size, breeding success, etc. The species appears to be a permanent resident at least in Argentina and Paraguay (Nores et al. 1983, Neris and Colmán 1991).

\section{Threats}

\section{Bolivia}

The chaco habitat in Tarija and Chuquisaca is being cleared in places for water and oil prospecting (T. A. Parker verbally 1992) which, as in other parts of the chaco, is associated with human colonization and thus further deforestation.

\section{Paraguay}

Neris and Colmán (1991) noted the increasing deforestation of the central Paraguayan chaco for agriculture and cattle-raising. This deforestation became more severe after the settlement of Mennonite farmers during the early decades of the 1900s; although they started with a subsistence economy based on agriculture, from the 1950s onwards they modernized their technology and thus production increased enormously, inevitably involving deforestation at an alarming rate for additional farmland, pasture and wood extraction (notably "quebracho colorado" Schinopsis balansae). Furthermore, electricity in the Mennonite colonies (e.g. at Filadelfia, Loma Plata) is produced by wood burning in electric plants. Another reason for concern is the relatively recent (early 1980s) introduction of the "jojoba" Simmondsia chinensis, notably in the relatively pristine chaco near the Bolivian border, resulting in large areas being cleared. This plant from the Sonoran Desert of Mexico and the U.S.A. is cultivated for the production of fine oils and cosmetics.

\section{Argentina}

Bucher and Nores (1988) and Canevari et al. (1991) indicated that the species may be negatively affected by the destruction of its natural habitat. This is clearly reflected by the notable absence of records from the dry chaco, undoubtedly owing to the extensive logging of quebracho (Aspidosperma spp., Schinopsis balansae) and algarrobo (Prosopis spp.) for charcoal, tannins, railway sleepers and land clearance for agriculture, which has occurred on a vast scale since European colonization and continues today. Much of the land in which the species was previously recorded in area C (see Figure 1) is now deforested, accounting for the lack of recent records. 


\section{Conservation}

Protection in the form of managed reserves is urgently required to secure the habitat where the two remaining healthiest populations occur: the dry chaco forest of west-central Paraguay (area A) - i.e. the "central Paraguayan chaco" and the dry forest in the sierras of Córdoba (area D). Within these areas the species only receives protection in Argentina's Chancaní and Copo Provincial Parks $(4,920$ ha and 114,250 ha respectively; protection in the latter is insufficient), both areas deserving more attention from the conservation point of view (J. C. Chebez in litt. 1992). The population in the central Paraguayan chaco is clearly under great threat (see Threats) and the creation of reserves there is of great priority before yet another population disappears. In Paraguay the species should be searched for in Teniente Enciso and Tinfunqué National Parks, which are adjacent to area A (F. E. Hayes in litt. 1992). Meanwhile, ecological and population studies are needed in order to design a network of reserves that would guarantee the species's survival in the long term. Additionally, in the Paraguayan chaco the main Mennonite colonies desperately need electrification in order to avoid wood burning for electricity; this should be available from Itaipú Binational Dam in the Paraná basin (F. E. Hayes in litt. 1992). The status of the species in Bolivia and in the Argentine chaco of Salta, western Formosa and Chaco, including its possible presence in Chaco National Park and Formosa National Reserve (J. C. Chebez in litt. 1992), needs clarifying as well as in the hybridization zone (area B in Figure 1 ).

\section{Remarks}

1. Short (1982) erroneously referred to the species as occurring in Chuquisaca department, Bolivia; Remsen et al. (1986, 1987) published the details of this record (given to them by Short) as: " $\mathrm{CH}$ [Chuquisaca]: Monteagudo, $325 \mathrm{~m}, 13$ May 1917 (Mus. Comp. Zool. \#86762)". Paynter (1992) spotted this mistake (also present in Remsen and Traylor 1989); the specimen was collected by L. M. Dinelli in Monteagudo, Tucumán (R. A. Paynter in litt. 1992).

2. Although Cabanis (1883) only indicated that the species was observed in "central Argentine" by M. F. Schulz, the type-locality has been attributed to Tucumán (e.g. Cory 1919, Peters 1948, Pergolani de Costa 1962), while Dabbene (1915) indicated that it was discovered by Schulz in Córdoba.

3. This refers to different dates of observation without taking into account the number of birds observed on each given date.

4. Records nos. 18 and 19 are sightings and it is therefore difficult to assess whether these birds might have been hybrids as well.

5. The records in Salta, Tucumán and western Santiago del Estero (Figure 1 and Appendix) are on the western edge of the chaco and in the transitional forest with the "yungas" (see, e.g., Figure 1 in Nores and Cerana 1990, and the map in Esteban 1969: 93). 


\section{Acknowledgements}

We would like to extend our thanks to the following persons for putting their personal observations or information/comments at our disposal: J. Fjeldså, F. E. Hayes, P. V. Hayman, F. R. Lambert, M. Nores, T. A. Parker, R. A. Paynter, G. Pugnali, M. Sulley, B. M. Whitney and D. Yzurieta, with a special mention for J. C. Chebez and R. J. Straneck for their interest and effort in obtaining a number of records which greatly improved this paper; to R. Ranft of the British Library of Wildlife Sounds, National Sound Archive, London, for the use of audio-spectogram instrumentation and the production of sonagrams; to V. I. Mees-Balchin and R. J. Straneck for use of recorded vocalization material; to A. J. Long (ICBP) for preparing the map and adapting the sonagram; to $\mathrm{M}$. LeCroy (AMNH), J. R. Navas (MACN), R. A. Paynter (MCZ) and R. W. Storer (UMMZ) for providing specimen data from their museums, and to P. R. Colston and R. P. PrŷsJones for permission to study skins in BMNH. Some of the preparation of this paper was undertaken as part of ICBP's Red Data Book programme, and it was completed with the use of ICBP's facilities and database.

\section{Appendix. Summary of the records for Black-bodied Woodpecker Dryocopus schulzi throughout its range.}

\begin{tabular}{|c|c|c|c|c|}
\hline Country & Location/Coord./Alt. (m) & Date & $\begin{array}{l}\text { No. of } \\
\text { birds } \\
\text { involved }\end{array}$ & Source \\
\hline $\begin{array}{l}\text { Bolivia } \\
\text { (Santa Cruz) }\end{array}$ & $\begin{array}{l}\text { (1) Cerro Picacho, Comarapa } \\
17^{\circ} 53^{\prime} \mathrm{S} 64^{\circ} 30^{\prime} \mathrm{W}(1,800)\end{array}$ & 23.01 .91 & ${ }^{*} 2$ & Clarke 1991 \\
\hline \multirow[t]{3}{*}{$\begin{array}{l}\text { Bolivia } \\
\text { (Tarija) }\end{array}$} & $\begin{array}{l}\text { (2) Villa Montes } \\
\left.21^{\circ} 15^{\prime} \mathrm{S} 63^{\circ} 30^{\prime} \mathrm{W} \text { (c. } 600\right)\end{array}$ & $29 \cdot 10 \cdot 36$ & $*_{1}$ & $\begin{array}{l}\text { Bond and Meyer de Schauensee } \\
\text { 1942, Remsen et al. 1986, 1987 } \\
\text { Short 1982, ANSP }\end{array}$ \\
\hline & & 30.10 .36 & 1 & Remsen et al. 1986, 1987 \\
\hline & & $4.11 \cdot 36$ & 1 & Remsen et al. 1986, 1987 \\
\hline $\begin{array}{l}\text { Paraguay } \\
\text { (Nueva } \\
\text { Asunción) }\end{array}$ & $\begin{array}{l}\text { (3) Teniente Enciso } \\
21^{\circ} 15^{\prime} \mathrm{S} 61^{\circ} 30^{\prime} \mathrm{W}\end{array}$ & $21.07 \cdot 75$ & 1 & $\mathrm{AMNH}$ \\
\hline \multirow[t]{10}{*}{$\begin{array}{l}\text { Paraguay } \\
\text { (Boquerón) }\end{array}$} & $\begin{array}{l}\text { (4) } 195 \mathrm{~km} \text { west of Puerto } \\
\text { Casada } \\
\text { C. } 22^{\circ} 05^{\prime} \mathrm{S} 59^{\circ} 45^{\prime} \mathrm{W}\end{array}$ & 7.06 .37 & 1 & UMMZ \\
\hline & & 9.06 .37 & $\mathbf{1}$ & UMMZ \\
\hline & & $20.03 \cdot 38$ & 1 & UMMZ \\
\hline & $\begin{array}{l}\text { (5) } 265 \mathrm{~km} W \text { Puerto Casado } \\
\text { c. } 22^{\circ} 10^{\prime} \mathrm{S} 60^{\circ} 15^{\prime} \mathrm{W}\end{array}$ & 24.06 .36 & I & Brodkorb 1937 \\
\hline & $\begin{array}{l}\text { (6) Orloff, Colonia Mennonita } \\
\text { c. } 22^{\circ} 19^{\prime} \mathrm{S} 60^{\circ} \mathrm{Oo}^{\prime} \mathrm{W}\end{array}$ & 28.11 .56 & 1 & Steinbacher 1962 \\
\hline & & 15.04 .57 & $\mathbf{1}$ & Steinbacher 1962 \\
\hline & $\begin{array}{l}\text { (7) Loma Plata } \\
22^{\circ} 21^{\prime} \mathrm{S} 59^{\circ} 50^{\prime} \mathrm{W}\end{array}$ & 8.12 .1988 & ${ }^{*} 1$ & F. E. Hayes in litt. 1991 \\
\hline & $\begin{array}{l}\text { (8) South of Filadelfia } \\
22^{\circ} 21^{\prime} \mathrm{S} 60^{\circ} 02^{\prime} \mathrm{W}\end{array}$ & 8.12 .1988 & ${ }^{*} 1$ & F. E. Hayes in litt. 1991 \\
\hline & $\begin{array}{l}\text { (9) Estancia (= Fortín) } \\
\text { Toledo } \\
22^{\circ} 21^{\prime} \mathrm{S} 60^{\circ} 20^{\prime} \mathrm{W}\end{array}$ & 22.01 .1988 & $*_{2}$ & F. E. Hayes in litt. 1991 \\
\hline & $\begin{array}{l}\text { (10) Estancia Campo Verde } \\
\text { C. } 22^{\circ} 25^{\prime} \mathrm{S} 60^{\circ} 30^{\prime} \mathrm{W}\end{array}$ & 27.07 .1989 & $*^{*}$ & A. Madroño Nieto \\
\hline
\end{tabular}


Appendix. (cont.)

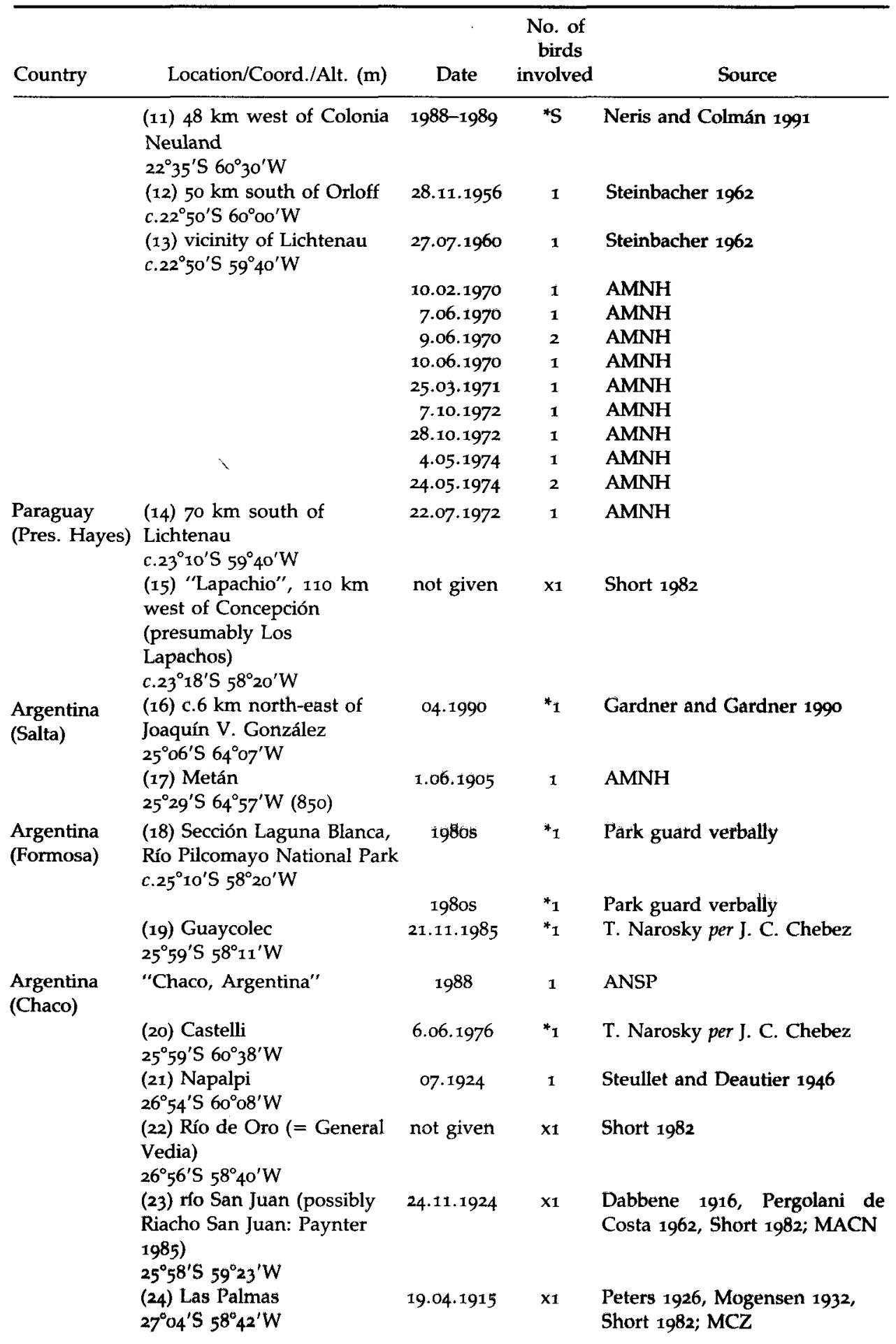


Appendix. (cont.)

\begin{tabular}{|c|c|c|c|c|}
\hline Country & Location/Coord./Alt. (m) & Date & $\begin{array}{l}\text { No. of } \\
\text { birds } \\
\text { involved }\end{array}$ & Source \\
\hline & $\begin{array}{l}\text { (25) Resistencia } \\
27^{\circ} 27^{\prime} \mathrm{S} 58^{\circ} 59^{\prime} \mathrm{W}\end{array}$ & $19.07 \cdot 1915$ & $\mathbf{x} \mathbf{1}$ & Peters 1926, Short 1982 \\
\hline & & 7.08 .1915 & $x I$ & Dabbene 1916,1926, Short 1982 \\
\hline & & 11.1915 & $x 1$ & Dabbene 1926 \\
\hline \multirow{13}{*}{$\begin{array}{l}\text { Argentina } \\
\text { (Santiago) } \\
\text { del Estero) }\end{array}$} & $\begin{array}{l}\text { (26) Reserva Provincial Copo } \\
26^{\circ} 05^{\prime} \mathrm{S} 62^{\circ} 00^{\prime} \mathrm{W}\end{array}$ & 18.02 .1989 & $*_{1}$ & $\begin{array}{l}\text { D. A. Gómez per J. C. Chebez in } \\
\text { litt. } 1992\end{array}$ \\
\hline & $\begin{array}{l}\text { (27) Las Termas } \\
27^{\circ} 29^{\prime} \mathrm{S} 64^{\circ} 52^{\prime} \mathrm{N}(260)\end{array}$ & 11.1929 & $\mathbf{1}$ & Dinelli 1931 \\
\hline & & 10.09 .1930 & 2 & Dinelli 1931; BMNH \\
\hline & & 15.09 .1930 & 3 & $\begin{array}{l}\text { Dinelli 1931, } \\
\text { Nores et al. 1991; IML }\end{array}$ \\
\hline & & 19.09 .1930 & 2 & Dinelli 1931, BMNH \\
\hline & & 20.09 .1930 & 2 & Dinelli 1931, BMNH \\
\hline & & 21.09 .1930 & 2 & Dinelli 1931, BMNH \\
\hline & (28) Villa Río Hondo & 8.04 .1947 & 1 & Nores et al. 1991 \\
\hline & $\begin{array}{l}27^{\circ} 34^{\prime} \mathrm{S} 64^{\circ} 57^{\prime} \mathrm{W} \\
(29) \text { Girardet } \\
27^{\circ} 37^{\prime} \mathrm{S} 62^{\circ} 10^{\prime} \mathrm{W}\end{array}$ & 09.1923 & 1 & Steullet and Deautier 1946 \\
\hline & $\begin{array}{l}\text { (3o) Campo del Cielo } \\
27^{\circ} 53^{\prime} \mathrm{S} 61^{\circ} 49^{\prime} \mathrm{W}\end{array}$ & 23.11 .1927 & 2 & Nores et al. 1991; MACN \\
\hline & $\begin{array}{l}\text { (31) Sierra de Guasayán } \\
28^{\circ} 00^{\prime} \mathrm{S} 64^{\circ} 50^{\prime} \mathrm{W}\end{array}$ & 28.10 .1980 & 2 & Nores et al. 1991 \\
\hline & $\begin{array}{l}\text { (32) Frías } \\
28^{\circ} 39^{\prime} \mathrm{S} 65^{\circ} \mathrm{og} 9^{\prime} \mathrm{W}\end{array}$ & 16.11 .1946 & 1 & Nores et al. 1991 \\
\hline & $\begin{array}{l}\text { (33) near Icaño } \\
28^{\circ} 41^{\prime} S 62^{\circ} 44^{\prime} \mathrm{W}\end{array}$ & 07.1903 & 1 & Ménégaux 1925, Nores et al. 1991 \\
\hline \multirow{13}{*}{$\begin{array}{l}\text { Argentina } \\
\text { (Tucumán) }\end{array}$} & “Tucumán” & 3.08 .1929 & 1 & $\mathrm{BMNH}$ \\
\hline & $\begin{array}{l}\text { (34) Trancas } \\
26^{\circ} 13^{\prime} \mathrm{S} 65^{\circ} 17^{\prime} \mathrm{W}(782)\end{array}$ & 10.1926 & 2 & Dinelli 1931; IML \\
\hline & $\begin{array}{l}\text { (35) Vipos } \\
26^{\circ} 29^{\prime} \mathrm{S} 65^{\circ} 22^{\prime} \mathrm{W}(786)\end{array}$ & 3.04 .1913 & 1 & Dabbene 1915; MACN \\
\hline & & $5 \cdot 07 \cdot 1917$ & 1 & MACN \\
\hline & $\begin{array}{l}\text { (36) Leales Medio } \\
\text { (presumably c. Leales) } \\
27^{\circ} 12^{\prime} \mathrm{S} 65^{\circ} 18^{\prime} \mathrm{W}(310)\end{array}$ & 15.08 .1915 & 1 & AMNH \\
\hline & $\begin{array}{l}\text { (37) Concepción } \\
27^{\circ} 20^{\prime} \mathrm{S} 65^{\circ} 35^{\prime} \mathrm{W}\end{array}$ & 3.02 .1909 & $\mathbf{1}$ & AMNH \\
\hline & & 8.07 .1916 & 1 & $\mathrm{MCZ}$ \\
\hline & & 26.10 .1924 & 1 & MACN \\
\hline & & $28.07 \cdot 1928$ & 1 & MACN \\
\hline & $\begin{array}{l}\text { (38) Monteagudo } \\
27^{\circ} 31^{\prime} S 65^{\circ} 17^{\prime} \mathrm{W}\end{array}$ & 13.05 .1917 & 1 & MCZ \\
\hline & $\begin{array}{l}\text { (39) Toro Muerto } \\
27^{\circ} 35^{\prime} \mathrm{S} 65^{\circ} 20^{\prime} \text { W?: Paynter } \\
1985\end{array}$ & 31.10 .1918 & 2 & $\mathrm{MCZ}$ \\
\hline & & 2.11 .1918 & $\mathbf{1}$ & $\mathrm{MCZ}$ \\
\hline & & 4.11 .1918 & 3 & $\mathrm{MCZ}$ \\
\hline
\end{tabular}


Appendix. (cont.)

\begin{tabular}{|c|c|c|c|c|}
\hline Country & Location/Coord./Alt. (m) & Date & $\begin{array}{l}\text { No. of } \\
\text { birds } \\
\text { involved }\end{array}$ & Source \\
\hline & Monte Toro (untraced) & $\begin{array}{l}12.08 .1910 \\
08.1910 ? \\
27.02 .1915 \\
28.02 .1915 \\
03.1915 ? \\
5.11 .1916\end{array}$ & $\begin{array}{l}1 \\
2 \\
1 \\
1 \\
2 \\
1\end{array}$ & $\begin{array}{l}\text { MACN } \\
\text { Dabbene } 1926 \\
\text { Dabbene 1926, MACN } \\
\text { Dabbene 1926, MACN } \\
\text { Dabbene 1926 } \\
\text { MCZ }\end{array}$ \\
\hline $\begin{array}{l}\text { Argentina } \\
\text { (Corrientes) }\end{array}$ & $\begin{array}{l}\text { (40) Laguna Pampín } \\
\text { c. } 27^{\circ} 30^{\prime} \mathrm{S} 58^{\circ} 45^{\prime} \mathrm{W}\end{array}$ & not given & 1 & Contreras and Contreras 1984 \\
\hline $\begin{array}{l}\text { Argentina } \\
\text { (Santa Fe) }\end{array}$ & $\begin{array}{l}\text { (41) Tostado } \\
29^{\circ} \times 4^{\prime} \mathrm{S} 61^{\circ} 46^{\prime} \mathrm{W}\end{array}$ & 26.01 .1945 & $\mathrm{I}$ & Giai 1950; MACN \\
\hline \multirow[t]{18}{*}{$\begin{array}{l}\text { Argentina } \\
\text { (Córdoba) }\end{array}$} & $\begin{array}{l}\text { (42) south-east of San } \\
\text { Marcos Sierra } \\
\text { c. } 30^{\circ} 44^{\prime} \mathrm{S} 64^{\circ} 48^{\prime} \mathrm{W} \\
\text { (43) base of Cerro Uritorco } \\
\text { Capilla del Monte } \\
\left.30^{\circ} 48^{\prime} \mathrm{S} 64^{\circ} 41^{\prime} \mathrm{W} \text { (c. } 1,000\right)\end{array}$ & late $1980 \mathrm{~s}$ & $\mathrm{n} ?$ & $\begin{array}{l}\text { A. Johnson per J. C. Chebez in } \\
\text { litt. } 1992 \\
\text { G. Pugnali per J. C. Chebez in } \\
\text { litt. } 1992\end{array}$ \\
\hline & & 13.03 .1991 & $*_{1}$ & M. Pearman et al. \\
\hline & & 03.1991 & ${ }^{*} 1$ & F. R. Lambert verbally 1992 \\
\hline & & 10.05 .1991 & $*_{1}$ & M. Sulley verbally 1992 \\
\hline & & 6.10 .1991 & $*_{1}$ & P. Hayman verbally 1992 \\
\hline & & 17.11.1991 & $*_{1}$ & B. M. Whitney in litt. 1991 \\
\hline & $\begin{array}{l}\text { (44) Quebrada Honda, } \\
\text { Unquillo } \\
31^{\circ} 14^{\prime} \mathrm{S} 64^{\circ} 20^{\prime} \mathrm{W} \text { (c. } 500 \text { ) }\end{array}$ & $\begin{array}{r}18.11 .1991 \\
6.06 .1988\end{array}$ & $\begin{array}{l}*_{1} \\
*_{2}\end{array}$ & $\begin{array}{l}\text { B. M. Whitney in litt. } 1991 \\
\text { M. Nores in litt. } 1992\end{array}$ \\
\hline & $\begin{array}{l}\text { (45) Córdoba } \\
31^{\circ} 24^{\prime} \mathrm{S} 64^{\circ} 11^{\prime} \mathrm{W} \\
(46) \text { Parque Provincial } \\
\text { Chancaní } \\
31^{\circ} 24^{\prime} \mathrm{S} 65^{\circ} 27^{\prime} \mathrm{W}(620)\end{array}$ & $\begin{array}{l}29.08 .1939 \\
\text { currently }\end{array}$ & 1 & $\begin{array}{l}\mathrm{MCZ} \\
\text { Canevari et al. 1991, and from } \\
\text { information sent by R. J. Straneck } \\
\text { in litt. } 1992\end{array}$ \\
\hline & $(=$ Los Pocitos $)$ & 27.08 .1980 & $*_{2}$ & $\begin{array}{l}\text { D. Yzurieta per M. Nores in } \\
\text { litt. } 1982\end{array}$ \\
\hline & & 6.01 .1981 & $*_{2}$ & $\begin{array}{l}\text { D. Yzurieta per M. Nores in } \\
\text { litt. } 1992\end{array}$ \\
\hline & & 02.1989 & $*_{3}$ & $\begin{array}{l}\text { J. C. Chebez et al. in litt. } \\
1992\end{array}$ \\
\hline & $\begin{array}{l}\text { (47) Quebrada de la Mermela, } \\
\text { Chancaní } \\
31^{\circ} 25^{\prime} S 65^{\circ} 24^{\prime} \mathrm{W}(740)\end{array}$ & $10.07 \cdot 1992$ & $*_{2}$ & R. J. and M. Straneck in litt. 1992 \\
\hline & $\begin{array}{l}\text { (48) Alta Gracia } \\
31^{\circ} 4^{\circ} \mathrm{S} 64^{\circ} 26^{\prime} \mathrm{W}\end{array}$ & 15.02 .1977 & ${ }^{*} 1$ & M. Nores in litt. 1992 \\
\hline & & not given & $*_{2}$ & M. Nores in litt. 1992 \\
\hline & $\begin{array}{l}\text { (49) Serranita La Rancherita } \\
31^{\circ} 40^{\prime} \mathrm{S} 64^{\circ} 25^{\prime} \mathrm{W}\end{array}$ & undated & $*_{1}$ & D. Yzurieta verbally \\
\hline & $\begin{array}{l}\text { (50) Nono } \\
31^{\circ} 46^{\prime} \mathrm{S} 65^{\circ} \mathrm{Oo} \mathrm{O}^{\prime} \mathrm{W}(900)\end{array}$ & $\begin{array}{l}26.01- \\
8.02 .1987\end{array}$ & *S & $\begin{array}{l}\text { C. Henschke per R. J. Straneck } \\
\text { in litt. } 1992\end{array}$ \\
\hline & $\begin{array}{l}\text { (51) Villa General Belgrano, } \\
\text { Calamuchita }\end{array}$ & 20.12 .1988 & ${ }^{*} 1$ & R. J. Straneck in litt. 1992 \\
\hline & $31^{\circ} 59^{\prime} \mathrm{S} 64^{\circ} 32^{\prime} \mathrm{W}(740)$ & 1990-1992 & ${ }^{*} 5$ & R. J. and M. Straneck in litt. 1992 \\
\hline
\end{tabular}


Appendix. (cont.)

\begin{tabular}{|c|c|c|c|c|}
\hline Country & Location/Coord./Alt. (m) & Date & $\begin{array}{l}\text { No. of } \\
\text { birds } \\
\text { involved }\end{array}$ & Source \\
\hline & $\begin{array}{l}\text { (52) Castelar, Calamuchita } \\
31^{\circ} 60^{\prime} \mathrm{S} 64^{\circ} 32^{\prime} \mathrm{W}\end{array}$ & 18.12 .1990 & ${ }^{*}{ }_{1}$ & $\begin{array}{l}\text { M. Straneck per R. J. Straneck } \\
\text { in litt. } 1992\end{array}$ \\
\hline & $\begin{array}{l}\text { (53) Parador de la Montaña, } \\
\text { Calamuchita } \\
\end{array}$ & 10.12 .1988 & $*_{1}$ & R. J. Straneck in litt. 1992 \\
\hline & $\begin{array}{l}\text { (54) Embalse del Rio Tercero } \\
32^{\circ} 12^{\prime} \mathrm{S} 64^{\circ} 28^{\prime} \mathrm{W} \\
(55) \text { Chulome, Calamuchita } \\
32^{\circ} 15^{\prime} \mathrm{S} 64^{\circ} 25^{\prime} \mathrm{W}(640)\end{array}$ & $\begin{array}{l}\text { undated } \\
\text { prior } 1967 \\
21.08 .1980\end{array}$ & $\begin{array}{l}*_{1} \\
*_{1}\end{array}$ & $\begin{array}{l}\text { A. Azategui per J. C. Chebez in } \\
\text { litt. } 1992 \\
\text { A. Azategui per R. J. Straneck } \\
\text { in litt. } 1992\end{array}$ \\
\hline \multirow[t]{3}{*}{$\begin{array}{l}\text { Argentina } \\
\text { (San Luis) }\end{array}$} & $\begin{array}{l}\text { (56) near Merlo } \\
\left.32^{\circ} 21^{\prime} \mathrm{S} 65^{\circ} \mathrm{O} 2^{\prime} \mathrm{W} \text { (c. } 800\right)\end{array}$ & 01.1986 & $*_{1}$ & $\begin{array}{l}\text { G. Pugnali per J. C. Chebez in } \\
\text { litt. } 1992\end{array}$ \\
\hline & $\begin{array}{l}\text { (56) Salto del Tabaquillo, } \\
\text { near Merlo } \\
\text { c. } 32^{\circ} 21^{\prime} \mathrm{S} 65^{\circ} \mathrm{O} 2^{\prime} \mathrm{W} \text { (c. } 800 \text { ) }\end{array}$ & 16.08 .1992 & *3 & $\begin{array}{l}\text { M. Babarskas per J. C. Chebez in } \\
\text { litt. } 1992\end{array}$ \\
\hline & $\begin{array}{l}\text { (57) La Estanzuela } \\
32^{\circ} 50^{\prime} \mathrm{S} 65^{\circ} \mathrm{O}^{\prime} \mathrm{W}\left(8_{40}\right)\end{array}$ & undated & $\mathrm{n} ?$ & Casares 1944 \\
\hline
\end{tabular}

Numbers before localities are matched with spots in Figure $1 ;{ }^{*}$, sight record; $x$, hybrid between schulzi and lineatus; S indicates "several" records, but number not specified; $\mathrm{n}$ ? applies to a record but number of birds involved unknown.

\section{References}

Bond, J. and Meyer de Schauensee, R. (1942) The birds of Bolivia, 1. Proc. Acad. Nat. Sci. Philadelphia 95: 167-221.

Brodkorb, P. (1937) Additions to the avifauna of Paraguay. Proc. Biol. Soc. Washington 50: $33-34$.

Bucher, E. H. and Nores, M. (1988) Present status of birds in steppes and savannas of northern and central Argentina. Pp. 71-79 in P. D. Goriup, ed. Ecology and conservation of grassland birds. Cambridge, U.K.: International Council for Bird Preservation (Techn. Publ. 7).

Burmeister, H. (1861) Reise durch die La Plata-Staaten. Halle: H. W. Schmidt.

Cabanis, J. (1883) Phloeotomus Schulzi n. sp. J. Orn. 31: 102-103.

Canevari, M., Canevari, P., Carrizo, G. R., Harris, G., Mata, J. R., Straneck, R. J. (1991) Nueva guía de las aves argentinas. Buenos Aires: Fundación Acindar.

Casares, J. (1944) Aves de Estanzuela, San Luis. Hornero 8 [1945]: 379-463.

Clarke, R. O. S. (1991) Field survey of the birds of the Comarapa valley and the cloud forests of Siberia, Dept. Santa Cruz, Bolivia. Unpublished.

Cory, C. B. (1919) Catalogue of birds of the Americas, Part II no. 2. Field Mus. Nat. Hist. Zool. Ser. 13 (Publ. 203).

Collar, N. J., Gonzaga, L. P., Krabbe, N., Madroño Nieto, A., Naranjo, L. G., Parker, T. A. and Wege, D. C. (1992) Threatened birds of the Americas: the ICBP Red Data Book. Third edition (part 2). Cambridge, U.K.: International Council for Bird Preservation.

Contreras, J. R. and Contreras, A. (1984) Addenda a la lista de aves no passeriformes de la provincia de Corrientes, Argentina. Historia Natural 3(28): 248.

Dabbene, R. (1910) Ornitología argentina. Buenos Aires: Imprenta y Casa Editora "Juan A. Alsina". (An. Mus. Nac. Buenos Aires [3]11).

Dabbene, R. (1915) Description d'un nouveau genère et d'une nouvelle espèce de pic 
provenant du nord-ouest de la République Argentine. An. Mus. Nac. Buenos Aires 27: 75-81.

Dabbene, R. (1916) Una subespecie aparentemente nueva de Neophloeotomos schulzi. Physis 2: 167-169.

Dabbene, R. (1926) Distribución geográfica del carpintero Neophloeotomus schulzi (Cab.). Hornero 3: 407-408.

Dinelli, L. M. (1931) Los carpinteros Dryotomus schulzii y Neophloeotomus shiptoni. Hornero 4: 415-417.

DSGM (1988) = Dirección Servicio Geográfico Militar (1988) Mapa del Paraguay (1: 2,000,000). Séptima edición. Dirección del Servicio Geográfico Militar.

Esteban, J. G. (1969) Protección de los recursos naturales en la Provincia de Tucumán (especialmente la fauna). Acta Zool. Lilloana 24: 89-98.

Frenzel, J. (1891) Uebersicht über die in der Provinz Córdoba (Argentinien) vorkommenden Vögel. J. Orn. 39: 113-126.

Gardner, N. and Gardner, D. (1990) A birder's guide to travel in Argentina. Unpublished.

Giai, A. G. (1950) Notas de viajes. Hornero 9: 121-164.

Hayes, F. E., Scharf, P. A. and Loftin, H. (1991) A birder's field checklist of the birds of Paraguay. Lake Helen, Florida: Russ's Natural History Books.

Hueck, K. (1972) Mapa de la vegetación de América del Sur, 1: 8,000,000. Stuttgart: Gustav Fischer Verlag.

Hueck, K. (1978) Los bosques de Sudamérica; ecologia, composición e importancia económica. Eschborn, Germany: Sociedad Alemana de Cooperación Técnica.

Lillo, M. (1902) Enumeración sistemática de las aves de la provincia de Tucumán. An. Mus. Nac. Buenos Aires (3)1: 169-221.

Ménégaux, A. (1925) Etude d'une collection d'oiseaux faite par M. E. Wagner dans le chaco argentin. Rev. Franc. Orn. 9: 322-329.

Mogensen, J. (1932) Algo más sobre los carpinteros, D. schulzi y N. shiptoni. Hornero 5: 63-64.

Narosky, T. and Yzurieta, D. (1987) Guía para las identificación de la aves de Argentina y Uruguay. Buenos Aires: Asociación Ornitológica del Plata.

Neris, N. and Colmán, F. (1991) Observaciones de aves en los alrededores de Colonia Neuland, Departamento Boquerón, Paraguay. Bol. Mus. Nac. Hist. Nat. Paraguay 10: I-10.

Nores, M., Yzurieta, D. and Miatello, R. (1983) Lista y distribución de las aves de Córdoba, Argentina. Córdoba, Argentina: Academia Nacional de Ciencias.

Nores, M., and Cerana, M. M. (1990) Biogeography of forest relics in the mountains of northwestern Argentina. Revta. Chilena Hist. Nat. 63: 37-48.

Nores, M., Yzurieta, D. and Salvador, S. A. (1991) Lista y distribución de las aves de Santiago del Estero, Argentina. Bol. Acad. Nac. Cienc. Córdoba 59 (3a-4a): 157-196.

Olrog, C. C. (1959) Las aves argentinas, una guía de campo. Tucumán: Universidad Nacional de Tucumán (Instituto Miguel Lillo).

Olrog, C. C. (1963) Lista y distribución de las aves argentinas. Tucumán: Universidad Nacional de Tucumán. (Opera Lilloana 9).

Olrog, C. C. (1979) Nueva lista de la avifauna argentina. Tucumán: Ministerio de Cultura y Educación, Fundación Miguel Lillo (Opera Lilloana 27).

Paynter, R. A. (1985) Ornithological gazetteer of Argentina. Cambridge, Mass.: Museum of Comparative Zoology.

Paynter, R. A. (1989) Ornithological gazetteer of Paraguay. Cambridge, Mass.: Museum of Comparative Zoology.

Paynter, R. A. (1992) Ornithological gazetteer of Bolivia. Second edition. Cambridge, Mass.: Museum of Comparative Zoology. 
Paynter, R. A., Traylor, M. A. and Winter, B. (1975) Ornithological gazetteer of Bolivia. Cambridge, Mass.: Museum of Comparative Zoology.

Pereyra, J. A. (1950) Las aves del territorio de Misiones. An. Mus. Nahuel Huapi 2: 3-38. Pergolani [de Costa], M. J. I. (1941) Los picidos argentinos. Hornero 8: 1-16.

Pergolani de Costa, M. J. I. (1962) Los picidos argentinos VI. Los Géneros Celeus Boie, Dryocopus Boie y Phloeoceastes Cabanis. Acta. Zool. Lilloana 18: 183-21o.

Peters, J. L. (1926) Two new birds from Argentina. Occas. Pap. Boston Soc. Nat. Hist. 5: 195-196.

Peters, J. L. (1948) Check-list of birds of the world, 6. Cambridge, Mass.: Harvard University Press.

Remsen, J. V. and Traylor, M. A. (1989) An annotated list of the birds of Bolivia. Vermillion, South Dakota: Buteo Books.

Remsen, J. V., Traylor, M. A. and Parkes, K. C. (1986) Range extensions for some Bolivian birds, 2 (Columbidae to Rhinocryptidae). Bull. Brit. Orn. Club 106: 22-32.

Remsen, J. V., Traylor, M. A. and Parkes, K. C. (1987) Range extensions for some Bolivian birds, 3 (Tyrannidae to Passeridae). Bull. Brit. Orn. Club 107: 6-16.

SAB (1982) = Sociedad Argentina de Botánica (1982) Conservación de la vegetación natural en la República Argentina. Tucumán: Ministerio de Cultura y Educación/Fundación Miguel Lillo.

Sclater, P. L. and Hudson, W. H. (1888-1889) Argentine ornithology. London: R. H. Porter. Short, L. L. (1975) A zoogeographic analysis of the South American chaco avifauna. Bull. Amer. Mus. Nat. Hist. 154: 165-352.

Short, L. L. (1976) Notes on a collection of birds from the Paraguayan Chaco. Amer. Mus. Novit. 2597.

Short, L. L. (1982) Woodpeckers of the world. Delaware: Delaware Museum of Natural History (Monogr. Ser. 4).

Sibley, C. G. and Monroe, B. L. (1990) Distribution and taxonomy of birds of the world. New Haven: Yale University Press.

SOMA [Sección Ornitológica del Museo Argentino de Ciencias Naturales] (1938) Lista sistemática de las aves argentinas. Hornero 7: 89-124.

Spichiger, R. and Ramella, L. (1989) The forests of the Paraguayan Chaco. Pp.259-270 in L. B. Holm-Nielsen, I. C. Nielsen and H. Halslev, ed. Tropical forests: botanical dynamics, speciation and diversity. London: Academic Press.

Steinbacher, J. (1962) Beiträge zur Kenntnis der Vögel von Paraguay. Senckenbergiana Biol. 49: $317-365$.

Stempelmann, H. and Schulz, F. (1889) Enumeración de las aves de la provincia de Córdoba, República Argentina. Bol. Acad. Nac. Cienc. Córdoba 10: 393-408.

Steullet, A. B. and Deautier, E. A. (1946) Catálogo sistemático de las aves de la República Argentina. Buenos Aires: Imprenta y Casa Editora "Coni" (Obra del Cincuentenario del Museo de la Plata [pt. 5]).

\section{ALBERTO MADROÑO NIETO \\ c/ Borox 54, 28042 Madrid, Spain.}

MARK PEARMAN

58 Prospect Place, Wapping Wall, London Er 9TJ, U.K. 